\title{
The Family Trust In New Zealand and the Claims
}

\section{of 'Unwelcome Beneficiaries'}

\author{
Sue Tappenden \\ School of Law, University of Waikato \\ E-mail: SUETAPP@waikato.ac.nz
}

\begin{abstract}
In June 2009, at the Transcontinental Trusts conference in Geneva, His Honour Justice David Hayton said that the New Zealand Court of Appeal had got aspects of the law of trusts wrong in its decision in Official Assignee v Wilson [2008] 3 NZLR 45. The Court held that the test for proving a trust was a sham was whether the trustees and settlor had a common intention that the trust was not to be a genuine entitiy. Hayton prefers a more objective approach and looks to the objective effect of a shammer's conduct and not look for secret dishonest intentions which will hardly ever be revealed. Hayton's approach would ensure that trust property would be made available to creditors so that they were paid what they were due by declaring the trusts to be shams. Family trusts have become big business in New Zealand and are commonly used to protect a businessman's assets from creditors. While there is nothing illegal in setting up a family trust, it is my contention that the law pertaining to family trusts in New Zealand has become so far removed from the accepted principles of equity as to demand investigation.

This paper explores the origins of equity and compares the modern family trust against the equitable principles which have been developed over hundreds of years, even as far back as Plato's Greece. The paper links the equity of Ancient Greece to Cicero in Rome, through the early Roman Church to the Chancellors serving English Kings. The law of England leads to the law of modern New Zealand. The paper goes on to examine the way the family trust has been used to defeat the legitimate claims of creditors. I aim to show that the approach taken by the New Zealand Court of Appeal is too narrow and favours the 'shamming' settlor at the expense of creditors who have given good consideration in comparison with volunteer beneficiaries. Moreover the family trust has become a mechanism that bears little relationship to recognised equitable principles and should lose the protection accorded to properly constituted trusts.
\end{abstract}

Keywords: Hayton, Objective, Intention, New Zealand

In June 2009, at the Transcontinental Trusts conference in Geneva, His Honour Justice David Hayton said that the New Zealand Court of Appeal had got aspects of the law of trusts wrong in its decision in Official Assignee v Wilson [2008] 3 NZLR 45. The Court held that the test for proving a trust was a sham was whether the trustees and settlor had a common intention that the trust was not to be a genuine entitiy. Hayton prefers a more objective approach and looks to the objective effect of a shammer's conduct and not look for secret dishonest intentions which will hardly ever be revealed. Hayton's approach would ensure that trust property would be made available to creditors so that they were paid what they were due by declaring the trusts to be shams. Family trusts have become big business in New Zealand and are commonly used to protect a businessman's assets from creditors. While there is nothing illegal in setting up a family trust, it is my contention that the law pertaining to family trusts in New Zealand has become so far removed from the accepted principles of equity as to demand investigation.

In Chudleigh's case in 1594 (Note 1) Sir Edward Coke said that there are "two inventors of uses [trusts] fear and fraud; fear in times of troubles and civil wars to save their inheritances from being forfeited; and fraud to defeat due debts, lawful actions, wards, escheats, mortmains, etc.”. Although the fear of losing inheritances through civil war may be past, many trusts are regularly created through a desire to avoid the claims of creditors, and what have been described as 'unwelcome beneficiaries'. (Note 2) The setting up of a family trust has been advertised as a smart move to ensure that a business is structured to operate in a financially beneficial way, protecting assets while paying the lowest possible tax.(Note 3). This particular firm refers to trusts as being 'a unique business form' and calls the settlors 'directors' of the trust who enjoy shared control of the assets with the other directors of the trustee company. Very often the companies promoting their services as trust advisers attract clients by offering to help them avoid tax, to shield their wealth from creditors, safeguarding against future inheritance taxes, showing them how to protect themselves against possible means testing on superannuation or medical or residential care benefits. The family trust is being sold as a clever way to make someone appear poor without him or her suffering the rigours of poverty.

While the law continues to assume that trusts are created for altruistic reasons, companies are selling their family trust services on the basis of the fringe benefits that a trust can confer. In fact if asked a client may reveal that the main 
reason for the creation of the trust was to defeat creditors. In the recent case of Taylor v Official Assignee which was heard in the High Court in Auckland in August 2009 the Court found that the Taylors had established their family trust to shield family assets from legitimate claims for unpaid taxes arising out of business activities and to place their primary assets out of the reach of creditors. This is not to say that there are not proper reasons for setting up a family trust. Commonly these are used as legitimate vehicles for the protection of children's assets in case of relationship break down, to prevent a second wife from taking $50 \%$ of the family assets without regard for the interests of the children of the first marriage.

A common selling point offered by purveyors of family trusts is to say that the settlors will retain control over the trust assets. Settlors pass assets and funds to the trust with themselves as trustees and, often without reference to any other trustee, continue to use those assets and funds as if they were their own. For example in Charman v Charman (Note 4) the English Court of Appeal developed a test to decide whether the assets in the trust had been used as a resource by the settlor. In Charman the husband had set up a discretionary trust of which he was settlor and one of a class of beneficiaries. He instructed the trustee company that they must consult him before taking any action with regard to the trust. Mr Charman had sole power to remove and appoint trustees. If he required any of the assets held by the trust they were to be transferred to him without question. He also told the trustees that they should regard him as the principle beneficiary during his lifetime and that all income should be held for him alone. At the time of the marriage break up the accumulated income of the trust was 4 million pounds and the trust's assets were valued at 68 million pounds. The husband appealed the trial judge's decision that the assets and income of the trust were in fact the property of the husband and therefore available to be included in the division of property between the spouses. The Court of Appeal dismissed his appeal because the husband had exerted so much control over the assets as to make them his property. Two earlier cases, In the Marriage of Ashton (1986)(Note 5) and In the Marriage of Goodman(1990) were heard by the Full Court of the Family Court of Australia where it was found that the husband in each case was in full control of the assets of the trust to the extent that the trust property was in fact the husband's own property.

Control of the trust can have far reaching consequences. In 2006 the Federal Court of Australia heard the case of Australian Securities \& Investments Commission v Carey (No 6) (Note 6) in which it was held that the trustee of a discretionary trust controlled the trust to the extent that the trustee was the alter ego of a beneficiary. In this case the property held in trust was seen to be the property of the beneficiary to the extent that receivers could take control of that property. This case turned on the effective control of the trust property which the court said could then be said to be included in the term "individual property" and therefore subject to the jurisdiction of the appointed receivers. These tests developed in the Australian case of Carey and the UK case of Charman to identify the settlor's 'control' and whether the trust assets were used as 'resources' do not hinge on intention by settlor or trustee. The courts in question were able to look through the trust to the reality of the consequences beyond the trust mechanism without the need to interpret intention as a central issue.

In the New Zealand case of Taylor the issue of intention was raised. This was related to s 60 of the Property Law Act 1952 where it was necessary to show "intent to defraud". However the Court cited the Supreme Court judgment in Regal Castings Ltd v Lightbody (Note 7) where the Court considered that the expression "intent to defraud" was "not happily chosen" and that the phrase had been considered as shorthand for intent to hinder, defeat or delay a creditor in the exercise of any right over the property of the debtor. The wording of Section 345(1)(a) of the Property Law Act 2007 reflects Blanchard J's interpretation of the way s 60 had come to be used. The new PLA demands that it be shown the debtor acted with intent to prejudice a creditor. Furthermore, the proof of intent in Taylor was arrived at by looking at the consequences of Mrs Taylor's actions. Her actions in transferring property to the Trust put the only valuable asset out of the reach of creditors and continuing to indulge in a lifestyle beyond her means put the Commissioner of Taxation at serious risk of not recovering the amounts owing. It was held that she must have intended this consequence even though it was not actually her wish to cause the commissioner loss at the time the trust was established. The Taylors may have intended to set up a trust at the onset of their dealings and the trust may have been validly constituted, but the subsequent actions of the parties, the deliberate ignorance of Mr Taylor and his wife's machinations were enough to allow the Court to remove the assets from the trust under their powers granted by S60 PLA 1952.

In New Zealand cases, even where there are no statutory provisions to be met, the issue of the parties' intentions at the time when a trust was created has become paramount. In Official Assignee v Wilson (Note 8) it was held that "there must be a common intention before a transaction is found to be a sham" meaning that both the settlor and the trustee must share a common intention to create an illusion of a trust before the court will find that the trust is a sham. Despite arguments like that of Jessica Palmer that the intention of a trustee has never been required in the creation of a trust, sham or otherwise, the Court of Appeal followed the line of cases established by Snook v London \& West Riding Investments (Note 9) and sought subjective intent on the part of the settlor and the trustee as parties to a transaction. This was said to be the determinate feature that determines whether an act or document was intended to be operative according to its tenor or whether it was meant to cloak another, different, transaction. 
It appears to me that this is the point at which the focus of the courts in these cases has been misdirected and because of this successful misdirection the misuse of equitable principles to hide assets has become obscured to the point where the courts seem to be interested only in the state of mind of the settlor and the trustee at the time of the formation of the trust. Once it has been accepted that the settlor and the trustee must have been ad idem in the purpose of creating some edifice that looked like a trust but in fact was something else entirely, it becomes almost impossible to penetrate the trust unless the circumstances can be said to allow section 357 of the Property Law Act 2007 to be used to set aside a transfer of property where it is detrimental to a creditor. However in most of the cases where the settlor intends to retain control of the trust assets and make use of the trust format as a device to protect those assets the settlor retains such control over the selection of the trustee that it is likely that the original trustee named at the creation of the trust would have been replaced several times, in accordance with the posers given to the settlor by the trust instrument. In those circumstances it is absurd to look for the intention of the trustee. The trustee's intention will simply be to retain the trust as a client and to adhere to the terms of the trust instrument to avoid breaching his fiduciary duty to the trust however it has been set up.

It is possible to see how settlors and the courts might have come to this point, where the certainties present at the time of the trust's formation have come to be more important than the way equitable principles are being used. The trust has come to be referred to as a 'transaction' or a 'business form'. Many trusts are advertised as being capable of operation as a trading business with profits spread among beneficiaries. Sometimes settlors are advised to link a settlor's limited liability company to the trust and utilised as the trustee. The trust has become associated with companies and the language of the company is commonly used when referring to a trust to the extent that looking through the trust mechanism is being likened to piercing the corporate veil. This is evident in $A v A$ (Note 10) where Munby $\mathrm{J}$ was considering an application to allow trust assets to be made available to meet a claim in the Family Division. Munby $\mathrm{J}$ refers to the three divisions of the High Court in England and says that there is "but one set of principles...equally applicable in all three Divisions, determining whether or not it is appropriate to "pierce the corporate veil'." Those divisions are Chancery, Family and the Queen's Bench. While it is clearly appropriate to talk of piercing the corporate veil when dealing with issues of breach of directors' duties I would contend that it is simply not appropriate to refer to corporate veils in relation to trusts, but if we accept the trust as being some alternative business form with the settlor's transfer of assets seen as a transaction then we are increasingly denying the importance of equitable principles in the operation of a trust. The family trust ceases to be a creature of equity, subject to equity's unique rules and becomes another way for a well informed person to hide assets from legitimate claimants.

In recent years fiduciary duties have been found to exist outside the trust and the more traditionally accepted roles of solicitor, trustee, agent etc. More and more we are importing fiduciary obligations into business transactions. The joint venture is a very good example of this where people bound by contract can find themselves also bound by equity. Sir Anthony Mason said in 1994 'Equity, by its intervention in commerce, has subjected the participants in commercial transactions, where appropriate, to the higher standards of conduct for which it is noted and has exposed the participants to the advantages and detriments of relief in rem'. It is true that there has been an attempt to bring to commerce a higher standard of trust and reliance in some circumstances. However this trend is undermined if we allow the blurring of the distinction between common law and equity to dilute or in any way erode or diminish the principles upon which equity was founded. It is those tenets that made the trust possible and it is not logical to now suspend those principles just because the elements of the three certainties that every law student must learn happen to be present. In some family trusts the form of a trust may be there but the essence of equity is not. In Official Assignee v Wilson (Note 11) at paragraphs 42 and 43 Robertson $J$ cites cases where the three certainties of intention, subject matter and object are discussed and he uses the case of Re Kayford Ltd (Note 12) as authority to say that a court cannot hold that a trust exists unless in the surrounding circumstances an intention to create a trust has been manifested. This is undoubtedly true. But it is not true that simply because an intention to create a trust exists that entity then becomes impervious to the rigours of equitable principles and may escape unscathed even when the consequences of the trust are that injustice is permitted to prevail.

It is sometimes said that equity has evolved far beyond its historical roots and that, while equity may have been created to thwart injustice, the liberal approach to equity, such as Lord Denning espoused is outdated. Graham Virgo describes today's equity as a 'technical system' administered by the Court of Chancery. Lord Denning's approached has, of course, been criticised heavily. For example in Dupont Steels Ltd v Sirs (Note 13) Lord Scarman referred to the purposive, liberal approach to judging as an 'unguided, even if experienced, sage sitting under the spreading oak tree'. Dr J Morris (Note 14) called it 'Palm Tree Justice in the Court of Appeal'. However other notions of equity still prevail such as overriding or correcting the effect of rules and embodying good conscience and natural justice.

Fifteen years ago Sir Anthony Mason expressed the purpose of equity in modern society:

...the ecclesiastical natural law foundations of equity, its concern with standards of conscience, fairness, equality and its protection of relationships of trust and confidence, as well as its discretionary approach to the grant of relief, stand in 
marked contrast to the more rigid formulae applied by the common law and equip it better to meet the needs of the type of liberal democratic society which has evolved in the twentieth century. (Note 15)

Despite this excellent description of modern equity it appears from some of the judicial pronouncements we have seen since that these standards of "conscience, fairness, equality" have been forgotten when dealing with family trusts. Instead of striving to maintain equitable standards courts have only looked at the form of the trust instrument and have become so fixated on questions of intention that the wider issues of whether equity has been served are lost. The other thing that strikes me in Sir Anthony Mason's words is his reference to equity's "discretionary approach to the grant of relief". This seems to have been forgotten in cases such as those that follow the Snook line of reasoning, that if the trust is to be a sham then common intention between the trustee and the settlor must be there at the beginning. For example in Shalson v Russo [2005] Ch 281 it was held that "unless that intention is from the outset shared by the trustee (or later becomes so shared) I fail to see how the settlement can be regarded as a sham." This reasoning led to the situation where the Official Assignee has to establish a common intention to create a sham trust by the settlor and the trustee at the outset (Official Assignee $v$ Wilson (Note 16). This requirement is tantamount to being insurmountable especially in cases where the settlor retains power to replace trustees who do not comply with his wishes. If the opinion expressed in $A v A \&$ St George (Note 17) is correct then a genuine trust (one where there is no common intention between the settlor and trustee) can never become a sham, even if a newly appointed trustee is the mere puppet of the settlor. Even if a subsequent trustee is removed for breach of trust the initial trust document remains valid, no matter what effect it may have.

I do not believe it is satisfactory to say that family trusts in New Zealand are often conducted in a manner which might be thought to be unconventional by reference to traditional concepts of trust administration. If family trusts are to be given the protections and flexibility offered by equity such as the imposition of fiduciary duties and the ability to split legal and equitable ownership, then the parties to the trust must also be bound by the higher standards imposed by equity. Sir Anthony Mason has identified the origins of those standards when he talks about the ecclesiastical beginnings of equity. But the obligations demanded by equity go back much further than the influence of the English chancellor on his King's conscience. The ecclesiastical monopoly over equity held by the king's chancellor dates from about 1274 when Edward I appointed Robert Burnell to the post of chancellor. Burnell was also Bishop of Bath and Wells from 1275. But the use of equitable principles to overcome the rigidity and shortcomings of the common law dates back to Plato in the $4^{\text {th }}$ Century BC.

Equity is not just a mechanism or 'business form' to be used for the advantage of businessmen, no matter how much this might seem to be the case from the attitude of many providers in the family trust industry. Instead equity is the product of thousands of years of philosophical consideration of the law and its relationship to justice.

In Plato's Statesman (or Politicus) the concept of equity is clearly articulated as being the conflict between the need to administer uniform law in general terms and the demands of justice in particular cases. Although Plato prefers the certainty of posited law "based on long experience and the wisdom of counsellors" he does leave some room for equity by recommending in The Laws, when the Athenian stranger replies to Cleinias, that every law should be issued with a preamble in order to expose the spirit of the written law. This idea was new in Plato's time and it is important because it offered for the first time the opportunity to distinguish between the spirit and the letter of the law. Nature appealed to the scholars of the $4^{\text {th }}$ century $\mathrm{BC}$ as the counterpart of law. At a later stage of philosophical development, most particularly with the advent of Stoicism, the law of nature began to be considered as a practical source of law. The explanation for this would appear to lie in the powerful development of equity in the jurisdiction of the democratic courts of this period.

Aristotle's contribution to the development of equity is generally accepted as being much greater than that of Plato. In the Nichomachean Ethics (Note 18) Aristotle identifies an "annex" to his main scheme of justice which is equity or fairness; the correction of the law in cases where the law is found to be deficient by reason of its universality. This is similar to Plato's expression of the concept of equity but Aristotle refines his articulation of equity in Rhetoric as being "justice that goes beyond the written law". Aristotle advises that when the written law is against us we should have recourse to "the general law and equity as more in accordance with justice" (Note 19) It is possible for us to see some actual examples of the use of equity in Ancient Greek courts through the translation of some of the speeches by orators of the time. In particular the speeches of Isaios show how the orators who were employed to plead cases made recourse to principles of equity in cases of contract and testamentary disposition. In many cases appeal to equitable principles was necessary because of the archaic nature of some of the laws and the extremely cumbersome legislative process. The Heliastic Courts represented the sovereign people and possessed wide discretionary powers, exercising a residuary justice which arose out of prerogative power. Later it was the monarch's prerogative power that enabled English Kings to depart from the common law and apply equity to promote justice in particular cases. This appeal by Greek orators to equity when faced with rigid or archaic statutes shows that equity was not merely an abstract conception but was an essential part of Greek justice. (Note 20) 
When the Greek city states were absorbed into the Macedonian Empire of Alexander the Great, the philosophers became less involved with politics and looked to the achievement of peace of mind in a changing world. The Stoics emerged as a movement that concentrated on the common humanity that united all people. Theirs was a conception of an ideal world state, in which everyone is a citizen living in harmonious order governed by a rational, universal set of rules - a law of nature binding on everybody. As the Macedonian Empire gave way to the growing power of the Roman Empire, the Romans adopted the Stoic concept of a universal natural law and used it to accommodate the legal systems of other communities into an overarching Roman law. This development in Roman philosophy was partly due to the great influence of Cicero, a Stoic and a prolific and gifted writer.

The writings of Cicero are an important step in the development of equity. Even at a time when rulers were supported by armies rather than philosophy, Cicero shows his sympathy with Plato in his belief that the pursuit of justice is the true aim of the state, with law fulfilling the role of the instrument that is used to achieve the state's aim. Later the English kings used equity to promote justice while exercising a prerogative power arising out of the status of the Crown as the origin of all law and justice. More proof that Cicero was influenced by the teachings of Plato can be seen in $D e$ Legibus where he says that it is the "crowd's definition of law" that identifies law with written decrees issuing commands and prohibitions. This would seem to be the attitude of judges who follow the Snook line of reasoning by taking the attitude that if the form of the trust exists in accordance with trusts law then it cannot be challenged even if it results in a terrible injustice. For Cicero "Justice is one; it binds all human society and is based on one Law, which is right reason applied to command and prohibition.". (Note 21) We can see here the same dichotomy that was previously expressed by Plato that exists between the written law and an unwritten standard of justice. There is another aspect of Roman Law that served to promote the development of equity which is the power enjoyed by the praetor, the Roman chief magistrate, to set aside the jus civile and to allow equitable defences and remedies. This would appear to be a clear expression of the influence of Greek philosophy. Gradually principles of equity and bona fides became prevalent in Roman jurisprudence. This is an important step as it was through the influence of the Roman Catholic Church that equity came to be the tool of English kings and chancellors.

As the influence of Christianity was felt on the Roman legal system, there was a reciprocal exchange of ideas from Roman law into the organization of the Church. The Christian Fathers lived under this Jurisprudence and it is not surprising that they adopted some ideas from the legal system of their home state and adapted them for use in the organizational structure of the new faith. Eventually the Bishop of Rome became a legislator for the whole of the Christian church just as the Emperors of the Roman Empire had legislated for all the citizens in their empire.

The reciprocal relationship between the Church and the Empire was in no way an immediate development and in fact it took several centuries. The early Christian church suffered persecution at the hands of the Romans until the first quarter of the fourth century when Constantine took the first crucial steps that linked the Church with Rome. There is a story that he had a vision on the eve of a battle after which he instructed his soldiers to put a Christian monogram on their shields. After winning the battle in 312 he continued to acknowledge his old religion based on the cult of the sun but at the same time he began to show favour to Christians by restoring their property that had been denied them while Christianity had been an illegal religion. He went on to make substantial gifts to Churches, in particular the Church of Rome, and by 320 the sun no longer appeared on new coins. Constantine came to see himself as responsible for the well being of the Church and in 324, having defeated an imperial rival who had been persecuting Christians, declared himself to be a Christian. In 325 he called the first ecumenical council at which 300 bishops attended who laid down a Creed. The Christian Church from that time had the protection of Imperial Rome and just as the Emperor ruled a united Roman Empire so too did the Pope of the Church of Rome aspire to ruling an all-embracing church. The laws promulgated by the Church were influenced by the Roman law and political organization, and Roman jurists adapted the ideas of the Christian Fathers, identifying the 'jus naturale' of Roman law with the law of God. The Christian church attained the charisma of Rome and Imperial power.

During the early middle ages in Europe the two main influences on philosophy were Christian doctrine and knowledge of Greek philosophy which was made available through the Latin texts of scholars like Cicero and Seneca. The influence of Cicero on the Roman legal system culminated in the Code written by the Emperor Justinian in the sixth century and its accompanying Digest. This great work was finished just as the barbarians destroyed the Roman Empire in the west. It is to these works that scholars will turn in the great revival of legal philosophy in the twelfth century. In the thirteenth century many of the works of Aristotle were rediscovered and translated once more changing the face of theological tradition.

The story of how Roman law theory of equity came to be incorporated into English law and from there to New Zealand is as follow. The Roman army abandoned England in the $5^{\text {th }}$ century leaving the country vulnerable to the invasion of barbarous Picts and Scots from the North and from the Jutes in the south east. Across Europe, in the wake of the Roman troops who were slowly converging on Rome to defend their homeland, the rule of Rome was displaced by the laws of the hordes that were sweeping across the empire, ripping it to shreds But even after the fall of the Roman Empire the 
influence of Roman jurisprudence did not altogether die out. The invading barbarian rulers who took over many of the Roman dominions compiled books of laws and preserved or imitated as much as they could of Roman culture and institutions. The influence of the Christian church was not entirely swept away during these dark years. Christianity had been established as the official religion of the Roman Empire a century before the fall of the Empire in the west and the Christian churches continued to look to the Church of Rome for guidance. Even though the Empire of Rome had fallen, the influence of the Church of Rome continued to expand. In 582 Pope Gregory sent Augustine and other monks to England where Ethlebert, who was at that time King of Kent, was converted. His wife was already a Christian, her family having been converted by earlier Christian pilgrims. The conversion of much of England followed, very often through the auspices of Christian queens who persuaded their husbands to look kindly on the religion that Saint Augustine of Canterbury and his monks were practicing. Paulinus converted Northumbria and established his see as Bishop of York. The seventh century saw the area of Northumbria flourish as an artistic, cultural and educational centre. Communication and exchanges of ideas between the Church of Rome and the scholars of Northumbria continued.

So it was in this way that the influence of the Greek and Roman philosophers, who saw the role of the state as being a vehicle for the promotion of equity and justice, came to the English kings through Christian teaching and influenced the future development of English Law. From the end of the sixth century onwards Codes of Anglo-Saxon law were compiled and published. They were written in Anglo-Saxon, not Latin and were expressions of the laws of England but those laws show the direct influence of the Church. The Church lent a new sanctity to the King as defender of the faith. The Church laid stress on the motives and intention behind people's actions that modified older notions of liability for wrongdoing. In modern times we say that equity operates on the conscience of the person who has wrongfully taken or kept what was not his beneficially. The Church that had inherited the ideas of the older civilization acted as a bridge to the 'modern' world and so it was inevitable that what the Church passed on would be coloured by the theories of law and equity that had been assimilated from the ancient Roman and Greek world.

Equity that was available for dispensation by the English Kings after William I was in part a product of the influences that shaped legal philosophy throughout Europe for hundreds of years before the Normans came to Britain. The twelfth century brought a renaissance of civilization in Europe and the rediscovery of the Emperor Justinian's Corpus Juris, written in the sixth century but lost after the fall of the Roman Empire. Some of the countries of southern Europe were becoming more profitable. People had more leisure time and were becoming more cultured. There was a great desire for knowledge of all sorts, and a need for a form of law that would befit the emerging enlightened world.

In eleventh century England William I began the process of securing his power against the local lords and establish his own royal power incorporating centralized power and a common law. However the laws that he enacted were of less importance than the English laws that were already in existence at the time of his accession. The laws of Edward the Confessor (1042-1066) were confirmed and the Christian religion was preserved. During the reigns of William I, William II and Henry I some laws were enacted but against a background of the customary law which must now adapt to the new situation created by the Conquest.

We are very fortunate in the fact that some of the early records of the Curia Regis were preserved. These are first hand materials showing the development of the Common Law beginning in 1194. The Plea Rolls give us an insight into the working of the Curia Regis in its early days and the cases that were decided there are the earliest authoritative statements of the Common Law. The influence of Henry the II on the law during his 35 year reign (1154-89) can be seen through the work of his clerks; usually men in Holy Orders, who compiled, illustrated and coordinated the information available in the court rolls. From the early years of his reign pleas were heard by itinerant judges who visited the counties and among them was Thomas Becket when he was Henry's Chancellor. In 1178 the King chose five men, two clerics and three laymen to form a permanent King's Court. This was to be a body of men who dispensed justice habitually in a central court. Most important from the point of view of the story of equity is the reserve of justice which remained in the King himself. One of those who were chosen to do this work was lawyer Ranulf de Glanvil who acted as counsellor and adviser to King Henry II. Glanvil was influential in the great strides made in the reform of English law and the founding of the common law by the King and it is said that he invented the action of Replevin. His fame comes to us through a book ascribed to his authorship but which is probably the work, at least in part, of his nephew, Hubert Walter who later became Archbishop of Canterbury and chancellor. Glanvil's treatise is a work of fourteen volumes and gives details of the differences between criminal and civil pleas, the pleas that were heard in the King's court and which were heard in other courts. Glanvil gives detailed accounts of the relationship between the king's courts and the ecclesiastical courts.

The earlier King's court was not fettered by rules of precedent and the judges showed they were willing to act on principles of equity. For example the view taken of cases involving mortgage reflected the same attitude that was ultimately adopted by the court of Chancery. This is in stark contrast to the attitude to mortgages that came to be taken by the later Common law courts. As an educated man Glanvil was well versed in Roman law and there are some 
instances in the reforms of Henry where it is clear that the imprint of Roman law, with all its attendant influences, is present.

The rules of the King's court were, therefore, evolving at the hands of the ablest men of the day, men who had been educated in the Christian tradition, who used their knowledge of Roman law to rationalize the old customary law, adapting principles of Roman law to the needs of England. The remedies that could be dispensed by the King's court and the writs that could start action were not strictly limited. This court would not hesitate to overrule old customary law in the name of equity. It had a power and efficiency that made it superior to all its rivals. The Common law continued to be developed for some time by men who had been educated by the Catholic Church and whose ideas of law were influenced by Roman law.

However, gradually, and certainly by the reign of Edward I (1272-1307), lawyers ceased to be predominantly those from an ecclesiastical background and a distinct profession began to emerge. These new lawyers were not versed in the equitable elements of Roman law and therefore were not able to use Roman law to supplement the deficiencies of English law. For a while the common law remained flexible enough to continue to dispense equity in the royal courts. While the number of writs available was not fixed, the law could develop to meet new situations. The King's judges were not tied to rules of substantive law or procedure so they could continue to do equity.

Eventually, during the fourteenth century broad principles of law gave way to technical, less rational, adherence to rules. Before that time, however, we can see a new development which would enable the further development of equity. This comes about while Robert Burnell is chancellor to Edward I. In 1265 he emerged as one of Edward's clerks and after traveling in France with Edward, he became Edward's friend. In 1274 Edward made him chancellor and in 1275 he became Bishop of Bath and Wells. During his time as chancellor his position was akin to that of Prime Minister, trusted by the King and powerful in government. He was head of a commission of enquiry into serious corruption in the judiciary after which two out of every three judges from the Court of King's Bench and four out of every five of the judges of the court of common Pleas were dismissed.

Burnell was very active in Chancery and has been described by historians as the first of the great chancellors in English Law. While Chancery was not yet a court, or curia, it was receiving petitions when the King was absent from England. During Burnell's time in office the Chancellor ceased to follow the King whenever he went abroad and instead remained in England to respond to these petitions. It was during this time that Parliament, comprised of the House of Lords and the House of Commons, was established and the law of the church began to grow more and more distinct from the common law. Ecclesiastic courts were in competition with Royal courts and the legal profession had split into the two branches of attorneys and pleaders, who became known as serjeants. In Parliament the judicial discretion enjoyed by the King was vested in the King's Council which was assisted by judges in the enactment of laws. It was possible for cases to be brought before the King's council and frequently the King's response would be to tell the litigant to go to the common law. As yet the king's courts were still able to dispense equity from within the common law. However, as the common law courts became more and more bound by strict rules of procedure, the role of the King and his Chancellor changed to allow them to decide cases in equity for litigants who could have no redress in law.

The common law judges now advised litigants whose claims could not be satisfied in their courts to apply directly to the King and to those officials who were so close to the king that they were able to exercise his prerogative in his name. This responsibility therefore devolved to the Chancellor. The King's duty was to do justice even though the result is to overturn the decision of the common law court. The Chancellor as close adviser to the King and, having a state department of his own, was the obvious choice to act on the King's behalf. The equity that he dispensed was based on conscience in deciding what was morally right and equitable rules sat very comfortably with the canon rules with which the Chancellor, as a religious leader, would be very familiar.

The story of equity from this point is one of conflict between two systems of justice followed by reconciliation, but throughout that history there is a constant theme. The court that dispensed equity did so according to its own rules which remained rooted in the wisdom of Aristotle brought to the courts via the law of Rome through the Christian church. Equity is once again being dispensed by common law courts as it was in the King's Court of Henry II, and the availability of equitable remedies is dependent on the justice of the case. The discretionary nature of those remedies means that if justice will not be served by their application, the judge is not bound to hand down such a remedy. In the case of family trusts that serve no purpose but to act as a repository for assets that justice demands should be distributed to creditors, it is not within the province of equity to assist the settlor. In the Australian tax case of Raflands in the appeal to the High Court it was said that the courts can

"send a clear signal that they will not be deceived into giving effect to unreal transactions, just because such transactions are expressed in documents that, to a greater or lesser extent, observe legal forms and give effect to apparent legal objectives."

As far as finding common intention was concerned Heydon $\mathrm{J}$ said (Note 22) 
It may be inferred that, so far as the intention of the Settlor, Mrs Sommerville, was relevant, that intention was to be found in the minds of the Heran brothers, the principals of Mr Tobin, who was Mrs Sommerville's employer. So far as the intention of the Trustee, Raftland Pty Ltd, was relevant, the same was true in view of its directors and shareholders. In assessing that intention any evidence by Mr Tobin, the architect of the transactions, could be taken into account, particularly if it were adverse to the interests of his principals. It may also be inferred that the intention of Mr Carey as Trustee of the E \& M Unit Trust was the intention of Mr and Mrs Thomas, the controllers of that Trust, and that that intention was the same as that of the Heran brothers.

This is demonstrably a departure from the formalistic approach that is so often a product of the reasoning in Snook. The inflexible approach of the New Zealand courts in similar cases, involving allegations of sham is demonstrated by some older and some recent judgments.

In Paintin and Nottingham (Note 23) Turner $\mathrm{J}$ made it clear that, in New Zealand, "[t]he word 'sham' has no applicability to transactions which are intended to take effect, and do take effect, between the parties thereto according to their tenor". In an earlier decision in Bateman Television Ltd v Coleridge Finance Co Ltd, his Honour had remarked, to like effect: (Note 24)

"[T]he occasions on which Courts have set aside the form of a transaction as a 'sham' are confined to cases in which, really doing one thing, the parties have resorted to a form which does not fit the facts in order to deceive some third person, often the revenue authorities, into the belief that they were doing something else."

Later, in Mills $v$ Dowdall (Note 25), Richardson J postulated, as a test for sham, whether "the [documents do] not reflect the true agreement between the parties". Later still, in Marac Life Assurance Ltd v Commissioner of Inland Revenue, Richardson J emphasised that: (Note 26)

"The true nature of a transaction can only be ascertained by careful consideration of the legal arrangements actually entered into and carried out: not on an assessment of the broad substance of the transaction measured by the results intended and achieved or of the overall economic consequences."

This approach has laid the ground for a narrow operation of the doctrine of sham in New Zealand. So much was reaffirmed in the recent decision of the New Zealand Court of Appeal in Accent Management Ltd v Commissioner of Inland Revenue:

"[A]rtificiality and lack of commercial point (other than tax avoidance) are not indicia of sham. And the concepts of sham and tax avoidance are not correlatives. As well, while there are elements of pretence (and certainly concealment) associated with [the] transactions [here at issue], these are explicable on bases other than sham".

The principles of equity are being used as instruments in schemes allowing people to avoid their ordinary financial obligations while this narrow approach, with its emphasis on the evidence of intention to create a sham, prevails in New Zealand. This use is contrary to the very foundations of equity which is to supplement the common law in the pursuit of justice for which equity has been developed since Plato lived in Ancient Greece.

\section{References}

Taylor v Official Assignee. (2009). HC AK 2006-4-4-7115 [26 august].

'Dealing with the Emerging Popularity of Sham Trusts'. (2007). NZ Law Rev 81.

'The Place of Equity and Equitable Remedies in the Contemporary Common Law World' 110 LQR, 238-259

J Getzler. (2003). (ed) 'Restitution through the Looking Glass' in Rationalizing Property, Equity \& Trusts 83, 85.

Raftland Pty Ltd as trustee of the Raftland Trust $v$ Commissioner of Taxation. (2008). HCA 21.

Prebble. (1996). Criminal Law, Tax Evasion, Shams, and Tax Avoidance: Part II - Criminal Law Consequences of Categories of Evasion and Avoidance. 2 New Zealand Journal of Taxation Law and Policy 59 at 63-66.

\section{Notes}

Note 1. (1594) 1 Co Rep 113b,121b

Note 2. NZ Guardian Trust Co Ltd advice leaflet.

Note 3. Company Solutions Ltd. information leaflet

Note 4. [2007] EWCA Civ 503

Note 5. 11 Fam LR

Note 6. [2006] FCA 233 A.L.R. 475

Note 7.[2008] NZSC 87 at para [52]

Note 8.[2008] NZCA 122 [41 
Note 9.[1967] 2 QB 786 CA

Note 10. [2007] EWHC 99 (Fam)

Note 11. Supra $n 9$

Note 12. [1975] 1 All ER 604

Note 13. [1980] 1 WLR

Note 14. 82 LQR 196

Note 15. Supra 13

Note 16. Supra 14

Note 17. [2007] EWHC 99 (Fam)

Note 18. (Book V Ch 10)

Note 19. Freese translation Rhetoric 1.xv

Note 20. Vinogradoff, Historical Jurisprudence II (1922) $63-69$

Note 21. De Legibus I.42

Note 22. At para 169

Note 23. [1971] NZLR 164 at 175

Note 24. [1969] NZLR 794 at 813

Note 25. [1983] NZLR 154 at 160

Note 26. [1986] 1 NZLR 694 at 706 